[溶接学会論文集 第 37 巻 第 4 号 p. 152-161（2019）］

\title{
抵抗スポット溶接継手の疲労挙動に及ぼす鋼板強度レベル およびナゲット径の影響*
}

\author{
植松 美彦**, 川邊 直雄 ${ }^{* *}$, 柿内 利文 ${ }^{* * * *}$, 加藤 雄大 ${ }^{* * * * *}$, \\ 沖田 泰明 ${ }^{* * *}$, 松田 広志 ${ }^{* * *}$, 田川 哲哉***
}

Effects of material strength levels and nugget sizes on fatigue behavior of resistance spot welded steel sheets*

\author{
by UEMATSU Yoshihiko ${ }^{* *}$, KAWABE Nao ${ }^{* * *}$, KAKIUCHI Toshifumi****, KATO Yudai****, \\ OKITA Yasuaki $^{* * *}$, MATSUDA Hiroshi $^{* * *}$ and TAGAWA Tetsuya ${ }^{* * *}$
}

\begin{abstract}
Tensile-shear test blanks were fabricated using high strength and low carbon steel sheets with three different strength levels by a resistance spot welding (RSW) procedure. The nugget sizes were changed by controlling the welding process parameters, resulting in the nugget sizes of $3 \sqrt{t}, 4 \sqrt{t}$ and $4.7 \sqrt{t}$, where $t$ was the sheet thickness. Subsequently, tensile-shear static and fatigue tests were conducted to investigate the effects of strength levels of steels and nugget sizes on the mechanical properties of the welds. The tensile strength increased with increasing strength levels and nugget sizes. However, the fatigue strengths of the welds with the nugget sizes of $4 \sqrt{t}$ and $4.7 \sqrt{t}$ were nearly comparable irrespective of the strength levels of steels. That was because fatigue crack propagation life was dominant in the total fatigue life. In the welds with $3 \sqrt{t}$ nugget size, the steel with higher strength level exhibited lower fatigue strength. It could be attributed to the lower bonding strength along the corona bond in the high strength steel.
\end{abstract}

Key Words: Fatigue, Resistance spot weld, High strength steel, Nugget size, Corona bond

1. 緒言

自動車産業分野では燃費向上の観点から, 車体構造の軽量 化が強く求められている. しかし, 車体には軽量化と同時に 衝突安全性の確保なども求められ, 高剛性や高強度も材料の 重要な選択要素となる。 これらの要求に応えるため, 自動 車用鋼板の高強度化が進み, 抵抗スポット溶接（Resistance Spot Welding: RSW）継手部にも高張力〜超高張力鋼板が多 用されるようになってきた ${ }^{1-3)}$. 一方, 軟鋼板を高張力鋼板に 置き換える際に，RSW 継手の疲労強度に関する問題点が指 摘されている．軟鋼板 RSW 継手の疲労強度に関する研究は 数多く行われている ${ }^{4-12}$ が, 近年の高張力〜超高張力鋼板を 用いた研究では, 母材の降伏点や引張り強さなどの静的破壊 強度が向上しても, 必ずしもそれが RSW 継手の疲労強度向 上に結びつかないことが報告されている ${ }^{13-22)}$. 例えば東郷ら は, $980 \mathrm{MPa}$ 級超高張力鋼板と $270 \mathrm{MPa}$ 級軟鋼板の RSW 継 手を比較した場合, 疲労強度はほぼ同程度であると報告して いる ${ }^{14,15)}$. また, その原因は疲労寿命の大半を疲労き裂進展 寿命が占めるためと考えられている. しかし, Tanegashima らはRSW 継手の疲労試験を中断し, ナゲット部の断面観察

\footnotetext{
*受付日 2019年6月19日 受理日２019年9月10日

**正 員 岐阜大学 Member, Gifu University

***正 員 JFE スチール(株) Member, JFE Steel Corporation

*****岐阜大学 Gifu University

***** 岐阜大学大学院 Graduate School of Engineering, Gifu University
}

によって疲労き裂発生とそれに続く進展を経時的に確認し た. その結果, 高張力鋼板 RSW 継手であっても全寿命の $60 \%$ 程度をき裂発生寿命が占める場合があり，必ずしも全 寿命が疲労き裂進展寿命で占められるわけではないことを 示した ${ }^{19}$. 以上のように, 鋼板強度レベルが RSW 継手の疲 労強度向上に直接結びつかない理由は必ずしも定かでなく, 溶接部からの疲労き裂発生や進展などの基礎的な事象につ いても不明瞭な部分が多い. また， RSW 継手の強度を支配 する主因子として, 鋼材そのものの強度レベルのみでなく, ナゲット径など溶接条件も挙げられる ${ }^{23)}$. しかしながら, 特 に高張力〜超高張力鋼板の RSW 継手においては, ナゲット 径が疲労挙動に与える影響についても明らかでない.

そこで本研究では, 軟鋼 (270 MPa 級), 高張力鋼 $(590 \mathrm{MPa}$ 級), 超高張力鋼 (980MPa 級) の 3 種類の鋼板を母材とし, 同種の鋼板同士を接合した RSW 継手について, 引張りせん 断試験片を用いた引張りおよび疲労試験を行った。また， 溶接条件を変えることでナゲット径を $3 \sqrt{t}, 4 \sqrt{t}$ および $4.7 \sqrt{t}$ ( $t$ は板厚 $)$ とした試料も作製し, 疲労挙動に及ぼすナゲッ ト径の影響についても検討した.

\section{2. 実 験 方 法}

\section{1 供試材および接合条件}

供試材は, 270, $590,980 \mathrm{MPa}$ 級の 3 種類の鋼板である. 鋼板の厚さ $t$ は全て $1.6 \mathrm{~mm}$ であり, 抵抗スポット溶接によっ 
て Fig. 1 に示す引張りせん断試験片を作製した. 試験片形状 は, 日本工業規格のスポット溶接継手疲れ試験法（JIS Z $3138 ）$ に準拠している. 幅 $40 \mathrm{~mm}$, 長さ $140 \mathrm{~mm}$ の短冊形板 材を利用して $40 \mathrm{~mm} \times 40 \mathrm{~mm}$ の重ね代を設け，その中央に抵 抗スポット溶接を施した.

溶接機にはインバータ直流抵抗スポット溶接機, 電極に は $\mathrm{Cr}-\mathrm{Cu}$ 製 $\mathrm{DR}$ 形 (先端径 $6 \mathrm{~mm}$ ) を用いた。溶接条件として, 加圧力, 通電時間, 保持時間は溶接径を問わず一定とし, 溶接電流のみを変更した。継手の引き剥がしピール試験を 行って溶接電流とナゲット径の関係を取得し, ナゲット径 が $3 \sqrt{t}, 4 \sqrt{t}, 4.7 \sqrt{t}(t=1.6 \mathrm{~mm})$ となる溶接条件を選定した. 270 および $980 \mathrm{MPa}$ 材については 3 種類のナゲット径の試料 を全て作製したが，590MPa材については $4 \sqrt{t}$ のみとした.

\section{2 組織観察および硬さ試験}

組織観察では，試料をエメリー紙で 80 番から 4000 番まで順 次研磨し, バフ研磨により鏡面仕上げした。 その後, 溶接部の 巨視的観察用には $5 \%$ ピクラール (腐食時間 15 秒), 微視組織 観察用には $1 \%$ ナイタール（腐食時間 3 秒）を用いてエッチング を行い, 光学顕微鏡と走査型電子顕微鏡 $(\mathrm{SEM})$ で観察した. 硬さ試験には，マイクロビッカース硬さ試験機（MVK TYPE C, 明石製作所）を用い, 試験力 $2.942 \mathrm{~N}$, 保持時間 $30 \mathrm{~s}$ で行った。

\section{3 引張りおよび疲労試験}

引張り試験は, 島津製電気一油圧サーボ式試験機（容量

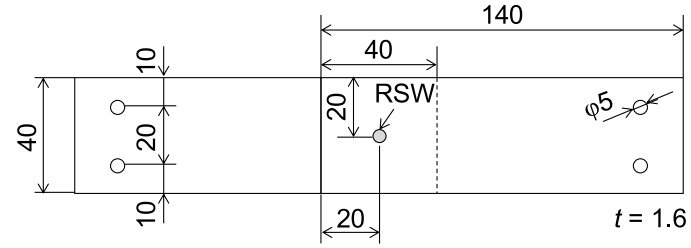

Fig. 1 Configuration of tensile-shear specimen.

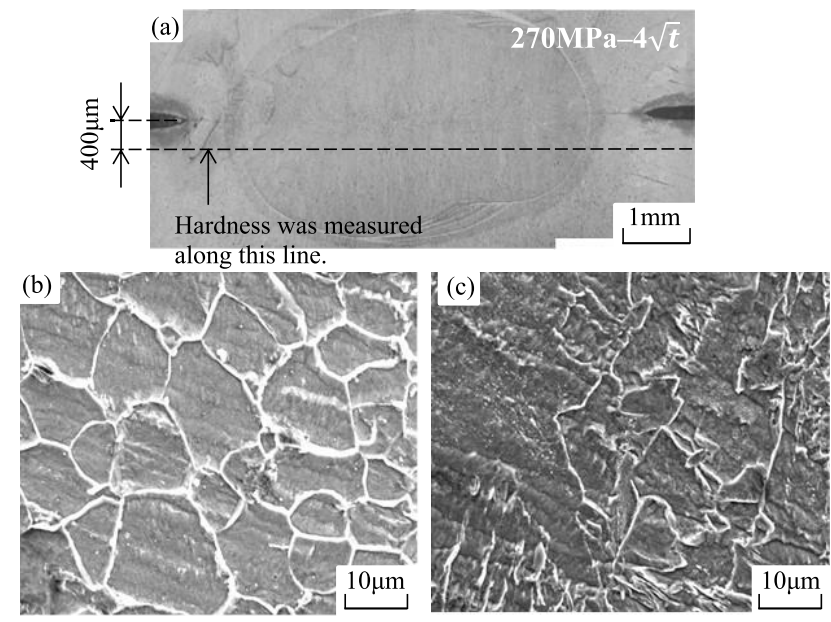

Fig. 2 Weld structures (270 MPa, $4 \sqrt{t}$ ): (a) Macroscopic view of the nugget, (b) Base metal, (c) Center of the nugget. 2t）を用い, クロスヘッド変位速度 $0.3 \mathrm{~mm} / \mathrm{min}$, 室温大気 中で行った。疲労試験は, 鴊宮製電気一油圧サーボ式疲労 試験機（容量 $5 \mathrm{t}$ ）を用いて行った。いずれの試験において も Fig.1の試験片に対し，JIS Z3138 に基づいて厚さ $1.6 \mathrm{~mm}$ のタブを溶接し, 引張りせん断時の負荷荷重軸が上板と下 板で一致するようにしている。試験条件は室温大気中，周 波数 $f=10 \mathrm{~Hz}$, 応力比 $R=0.1$ であり, 繰返し数 $10^{7}$ 回を試験 打ち切りの疲労限度と定義した。

\section{3. 実 験 結 果}

\section{1 組織様相}

Fig.2〜 4 は，それぞれ 270，590，980 MPa 級鋼板 $4 \sqrt{t}$ 材 のナゲット断面における組織様相である。いずれも, 試験 片の長手方向に対して垂直な横断面で観察を行った。各図 は (a)巨視的様相, (b) 母材微視組織, (c) ナゲット中央部微
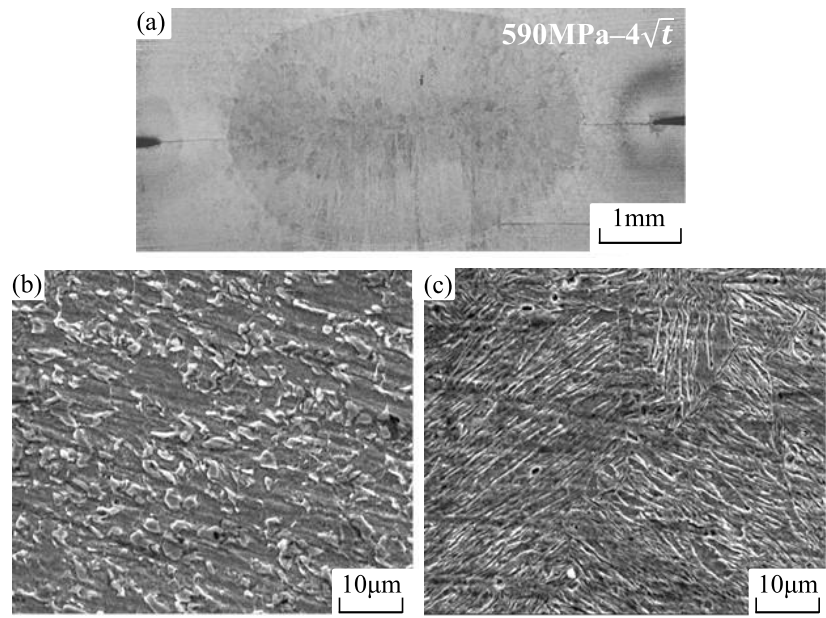

Fig.3 Weld structures (590 MPa, $4 \sqrt{t}$ ): (a) Macroscopic view of the nugget, (b) Base metal, (c) Center of the nugget.
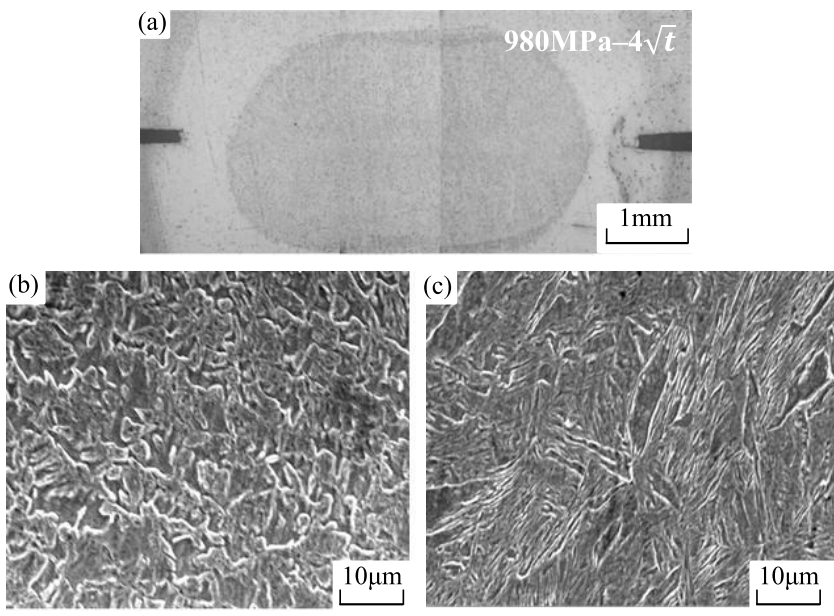

Fig. 4 Weld structures $(980 \mathrm{MPa}, 4 \sqrt{t}$ ): (a) Macroscopic view of the nugget, (b) Base metal, (c) Center of the nugget. 
視組織となっている. $270 \mathrm{MPa}$ 材 (Fig.2) では, 母材, ナゲッ ト中心部ともにフェライト相が支配的である．590（Fig.3） および $980 \mathrm{MPa}$ 材 (Fig.4）の母材部では, 強度上昇ととも にマルテンサイト相が増えるが，980 MPa材でも二相組織 （Dual Phase）となっている.また，いずれもナゲット中心 部 (Fig.3 (c), 4(c)) では, ほぼ全面がマルテンサイト相になっ ていることがわかる. Fig. 5 は $590 \mathrm{MPa}, 4 \sqrt{t}$ 材のナゲット 周囲の様相であるが，溶接時の温度上昇と圧力によって圧 接状態にあるコロナボンド (Corona bond) が鋼種やナゲッ ト径によらず全ての継手で確認された。

Fig. 6, 7 に, それぞれ $980 \mathrm{MPa}, 3 \sqrt{t}$ および $4.7 \sqrt{t}$ 材のナゲッ 卜横断面様相を示す．各図は (a) 巨視的様相， (b) ナゲット中 央部微視組織となっている. 同一鋼種 (980MPa 級) で比較 すると, Fig.4，6，7でナゲット径が異なることがわかる. また Fig.6(b)，7(b)のナゲット中央部では，いずれも Fig. 4(c) と同様にマルテンサイト相が支配的となっており,

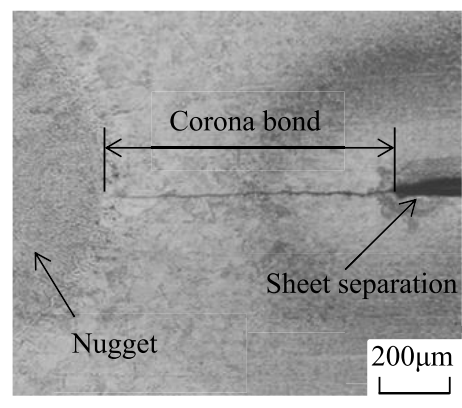

Fig. 5 Corona bond (590 MPa, $4 \sqrt{t})$.
溶融再凝固部の微視組織にナゲット径の影響は認められな かった.

\section{2 硬さ分布および引張り特性}

ナゲット断面における硬さ分布について, Fig.2(a)中の破 線で示すように板厚中央から $400 \mu \mathrm{m}$ 離れた位置で測定した. 得られた硬さ分布を Fig. 8 に示す。横軸はナゲット中央から の距離である。いずれの材料においても，ナゲット部の硬 さは母材部よりも上昇していることがわかる。組織観察で 示したように，ナゲット中央部でもフェライト相が支配的

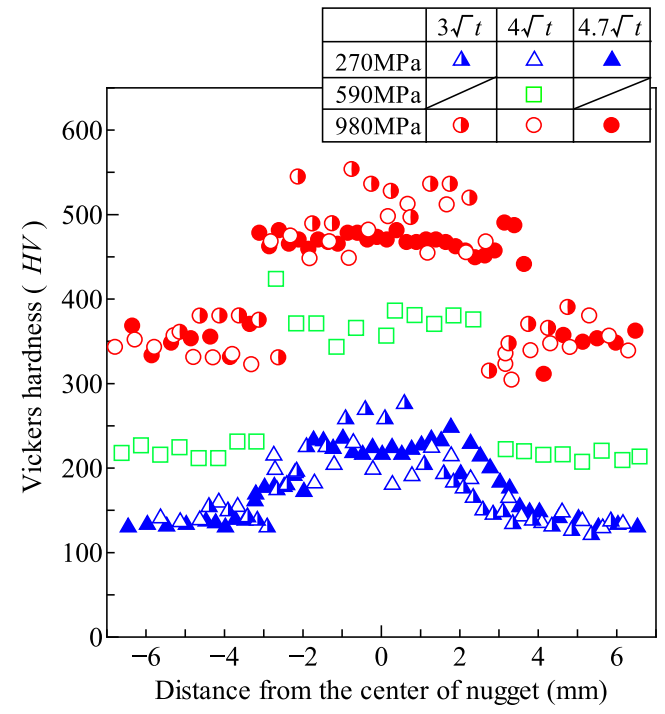

Fig. 8 Hardness profiles on the cross section of the nugget.
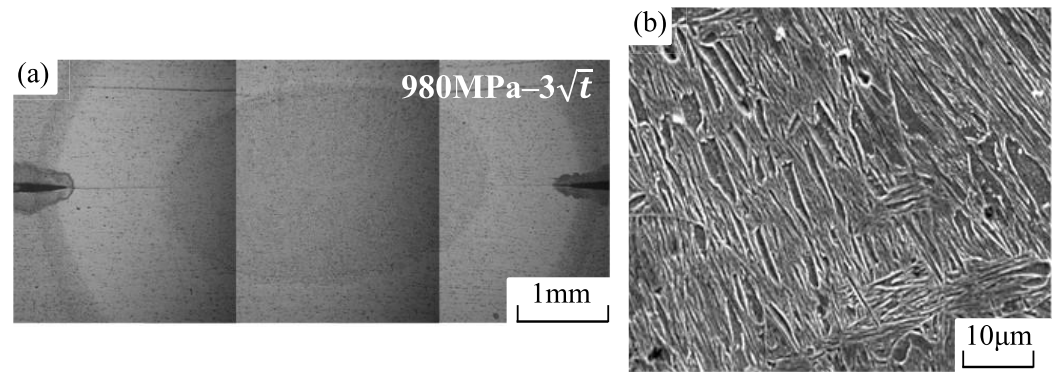

Fig. 6 Weld structures (980 MPa, $3 \sqrt{t}$ ): (a) Macroscopic view of the nugget, (b) Center of the nugget.
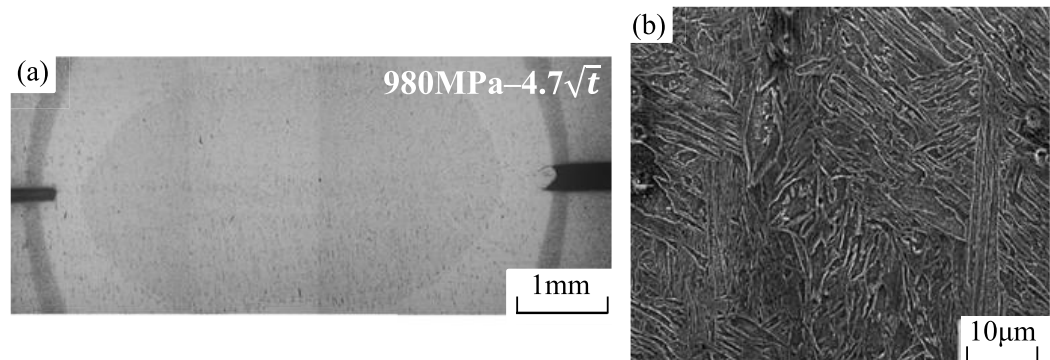

Fig. 7 Weld structures (980 MPa, 4.7 $\sqrt{t}$ ): (a) Macroscopic view of the nugget, (b) Center of the nugget. 


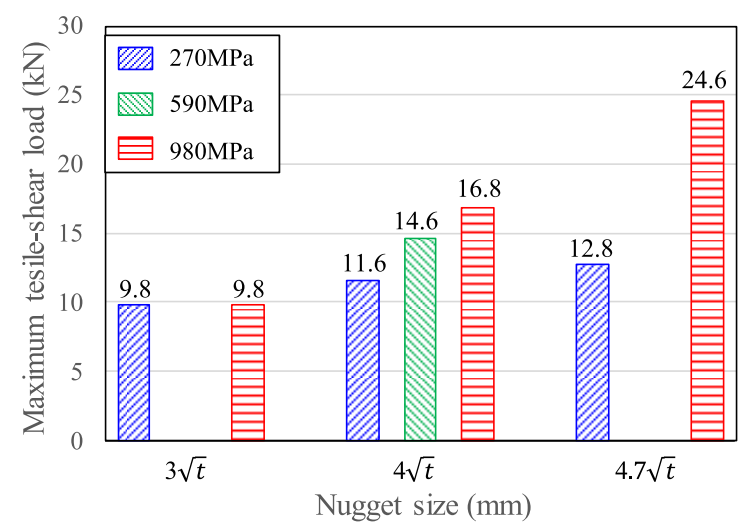

Fig.9 Maximum tensile-shear loads.

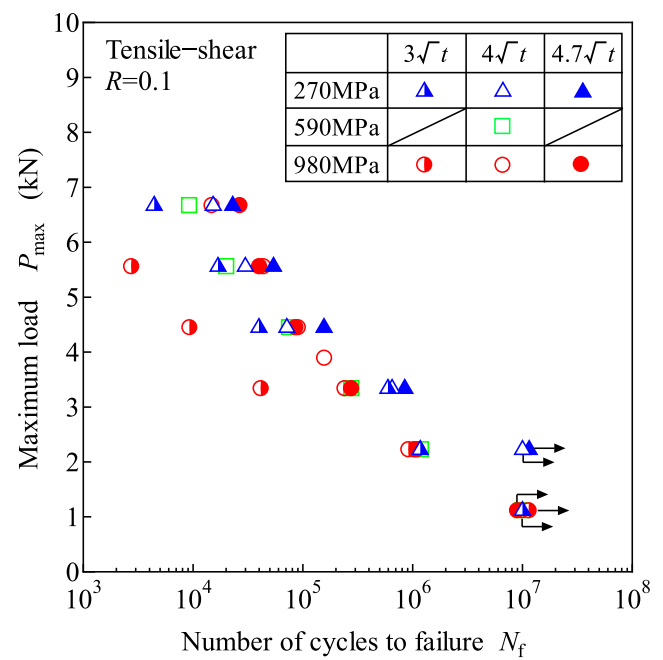

Fig. $10 P-N$ diagram.

な $270 \mathrm{MPa}$ 材と比較し, ほぼ全面マルテンサイトとなる 590, $980 \mathrm{MPa}$ 材の方がナゲット部での硬さ上昇が大きい. また, ナゲット径の大きさと硬化部の範囲は対応しており, ナゲット径が大きいほど硬化域も広い.

引張り試験で得られた最大引張せん断荷重を Fig. 9 に示 す. $270 \mathrm{MPa}, 4.7 \sqrt{t}$ 材のみがナゲット周りのボタン型破壊 となったが, その他の継手では, 鋼種やナゲット径によら ず全てナゲット部のせん断破壊であった. Fig.9 に示すよう に, 鋼種の強度レベルの向上, あるいはナゲット径の増大 とともに最大荷重も増加する傾向にある。しかし, $980 \mathrm{MPa}$ 材ではナゲット径の増大で大きく引張り強度が上昇するが, $270 \mathrm{MPa}$ 材では上昇の程度が小さい.これは $270 \mathrm{MPa}$ 材のみ, ナゲット径によって破壊モードが異なっていたためと考え られる。

\section{3 疲労特性}

疲労試験における最大荷重 $P_{\max }$ と破断繰返し数 $N_{\mathrm{f}}$ の関係 （ $P-N$ 線図）を Fig. 10 に示す。概ね全ての継手で疲労強度 は同等であるが, $980 \mathrm{MPa}, 3 \sqrt{t}$ 材のみ, 有限寿命域での疲

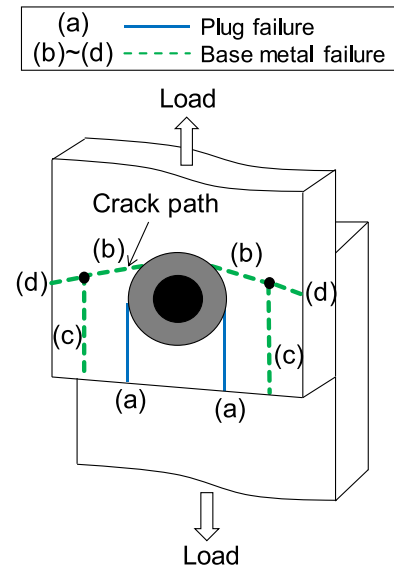

Fig. 11 Schematic illustration of failure modes ${ }^{19)}$.

労強度が低い. また $270 \mathrm{MPa}, 3 \sqrt{t}$ 材も若干低めとなっている. それ以外の継手では, 鋼種やナゲット径の影響は見られず, 全てほぼ同じ $P-N$ 曲線となった。一方, $10^{7}$ 回で試験を打ち 切った疲労限度に注目すると， $270 \mathrm{MPa}, 4 \sqrt{t}$ および $4.7 \sqrt{t}$ 材で若干高くなるものの, 全ての継手で大きな差は無い. すなわち， $980 \mathrm{MPa}, 3 \sqrt{t}$ 材は有限寿命域で疲労強度が低い ものの, 疲労限度は他の継手と同程度である。

継手の巨視的な疲労破壊形態には, 荷重依存性が認めら れた. Tanegashima らは, 疲労破壊形態の荷重依存性を Fig. 11 に模式的に示すように分類している ${ }^{19)}$. すなわち静的 破壊と同じナゲット部の界面破壊（Interface failure），ナゲッ 卜周りで破壊するプラグ破壊（Plug failure）および母材部 破壊（Base metal failure）である. 鋼種とナゲット径により， どのような疲労破壊が生じたのかを $270 ， 590 ， 980 \mathrm{MPa}$ 材 についてまとめたものをそれぞれ Table 1，2，3に示すが， 主として荷重が大きい場合およびナゲット径が小さい場合 に界面破壊が生じ, 荷重低下およびナゲット径の上昇に伴 い，プラグ破壊や母材破壊へと遷移する傾向が見られた. この傾向は，他の RSW 継手の疲労に関する研究結果とほほ 一致する ${ }^{14,15,19)}$.

\section{4. 考察}

\section{1 疲労特性に及ぼす鋼種の影響}

疲労特性に及ぼす鋼種の影響について検討するため, 270 および $980 \mathrm{MPa}$ 級鋼板の $4 \sqrt{t}$ 材を用い, 疲労中断試験を行っ た。これらの試験では， $P-N$ 線図に基づく破断繰返し数の $10 \%$ で試験を中断し, 試験片を長手方向に切断して Fig. 12 の模式図で示す観察領域で, ナゲット周囲におけるき裂の 有無を確認した. $P_{\max }=3.33 \mathrm{kN}$ および $5.56 \mathrm{kN}$ で行った中断 試験の結果をそれぞれ Fig. 13, 14 に示す。 それぞれの図で (a) が $270 \mathrm{MPa}$ 材，(b) が980MPa材となっている．いずれの継 手においても，シートセパレーション端部から疲労き裂が 発生していることがわかる.まずFig. 13(a)の 270MPa 材で 
Table 1 Failure modes in 270 MPa RSW joints.

\begin{tabular}{c|ccccc}
\hline \hline & $P_{\max }=6.67 \mathrm{kN}$ & $P_{\max }=5.56 \mathrm{kN}$ & $P_{\max }=4.44 \mathrm{kN}$ & $P_{\max }=3.33 \mathrm{kN}$ & $P_{\max }=2.22 \mathrm{kN}$ \\
\hline $270-3 \sqrt{t}$ & Interface & Interface & Plug & Base metal & Base metal \\
\hline $270-4 \sqrt{t}$ & Plug & Plug & Base metal & Base metal & Run out \\
\hline $270-4.7 \sqrt{t}$ & Plug & Base metal & Base metal & Base metal & Run out \\
\hline
\end{tabular}

Table 2 Failure modes in 590 MPa RSW joints.

\begin{tabular}{c|ccccc}
\hline \hline & $P_{\max }=6.67 \mathrm{kN}$ & $P_{\max }=5.56 \mathrm{kN}$ & $P_{\max }=4.44 \mathrm{kN}$ & $P_{\max }=3.33 \mathrm{kN}$ & $P_{\max }=2.22 \mathrm{kN}$ \\
\hline $590-4 \sqrt{t}$ & Interface & Interface & Base metal & Base metal & Base metal \\
\hline
\end{tabular}

Table 3 Failure modes in 980 MPa RSW joints.

\begin{tabular}{c|ccccc}
\hline \hline & $P_{\max }=6.67 \mathrm{kN}$ & $P_{\max }=5.56 \mathrm{kN}$ & $P_{\max }=4.44 \mathrm{kN}$ & $P_{\max }=3.33 \mathrm{kN}$ & $P_{\max }=2.22 \mathrm{kN}$ \\
\hline $980-3 \sqrt{t}$ & & Interface & Interface & Interface & Base metal \\
\hline $980-4 \sqrt{t}$ & Interface & Plug & Base metal & Base metal & Base metal \\
\hline $980-4.7 \sqrt{t}$ & Base metal & Base metal & Base metal & Base metal & Base metal \\
\hline
\end{tabular}

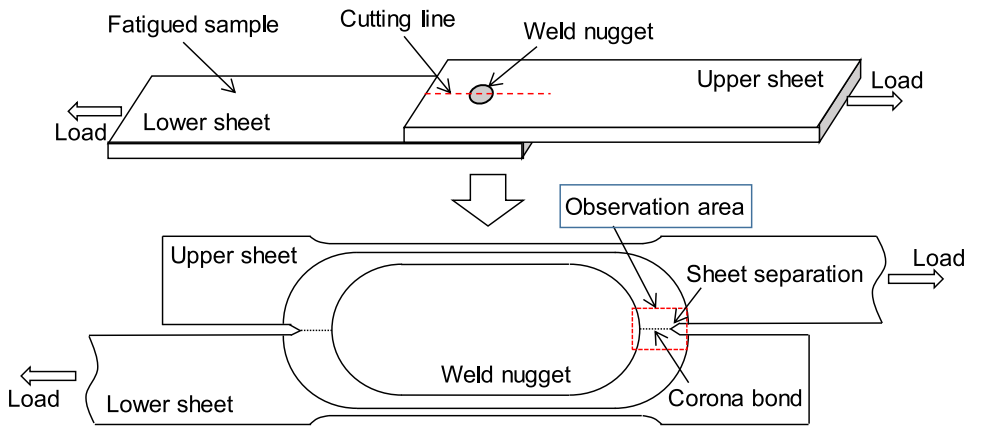

Fig. 12 Schematic illustration showing observation area of fatigued sample.

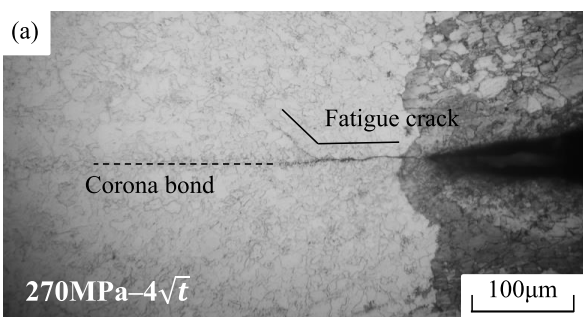

(b)

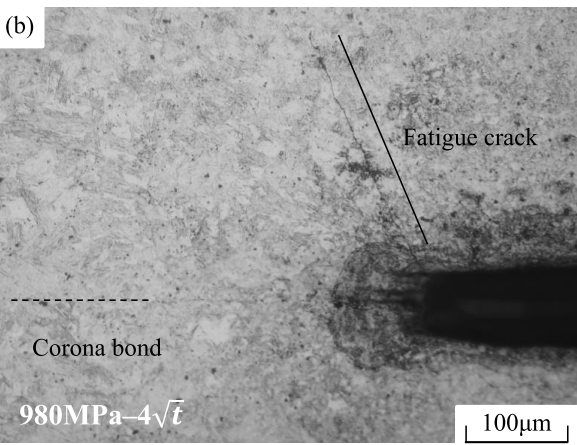

Fig. 13 Interrupted specimens at $10 \%$ of total fatigue life $\left(P_{\max }=3.33 \mathrm{kN}\right)$. The nugget size is $4 \sqrt{t}$.: (a) $270 \mathrm{MPa}$ class, $N=64,823, N_{\mathrm{f}}=$ 647,976 , (b) $980 \mathrm{MPa}$ class, $N=24,127, N_{\mathrm{f}}=241,034$. (a)

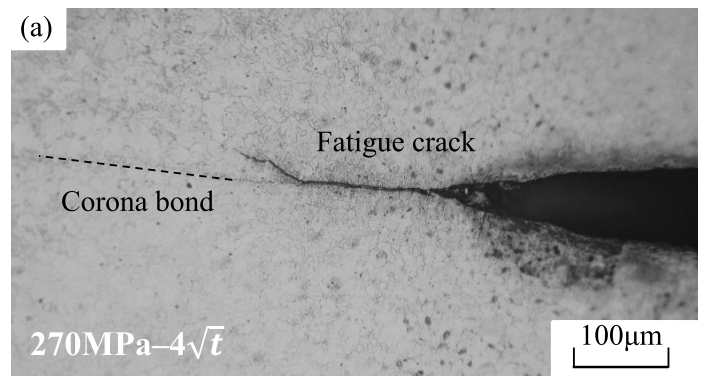

(b)

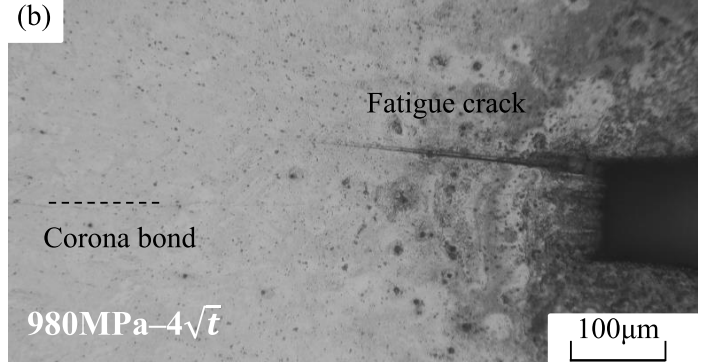

Fig. 14 Interrupted specimens at $10 \%$ of total fatigue life $\left(P_{\max }=5.56 \mathrm{kN}\right)$. The nugget size is $4 \sqrt{t}$.: (a) $270 \mathrm{MPa}$ class, $N=3,031, N_{\mathrm{f}}=$ 29,889 , (b) $980 \mathrm{MPa}$ class, $N=4,387, N_{\mathrm{f}}=43,874$. 
は，シートセパレーション端部からコロナボンドに沿って き裂が進むが, $100 \mu \mathrm{m}$ 程度で母材側へ経路がずれている. 一方 $980 \mathrm{MPa}$ 材 (Fig. 13(b)) では, シートセパレーション 端部からコロナボンドとは無関係に母材側へ斜めにき裂は 進展している。この荷重レベル $\left(P_{\max }=3.33 \mathrm{kN}\right)$ では, Table 1，3より 270 および $980 \mathrm{MPa}$ 材ともにき裂がシートセ パレーション端部近傍で発生し, 母材部で最終破壊する. すなわち, Fig. 13 のき裂はそのまま母材の板厚方向へ進展 して母材破壞に至ると考えられる。一方 $P_{\max }=5.56 \mathrm{kN}$ では, Fig. 14(a)に示すように270MPa 材では Fig. 13 と同様, シー トセパレーション端部からコロナボンドに沿ってき裂が進 展するが, $100 \mu \mathrm{m}$ 程度で母材側へ経路がずれる．Fig. 14(b) の $980 \mathrm{MPa}$ 材も，シートセパレーション端からコロナボン ドとは無関係にき裂が発生しており，Fig. 13 と同様の傾向 となった．この荷重レベルでは，Table 1 によれば $270 \mathrm{MPa}$ 材はプラグ破壊となっており, Fig. 14(a)でコロナボンドか ら逸れたき裂は, 板厚方向に進展してプラグ破断に至ると 考えられる。一方, $980 \mathrm{MPa}$ 材も Table 3 によればプラグ破 壊が生じており，シートセパレーション端部から直線的に $400 \mu \mathrm{m}$ ほど進展したき裂はやがて母材方向へ経路を変え, プラグ破断に至ると思われる。しかし，この荷重レベルは 界面破壊とプラグ破壞のほぼ遷移域に当たり，Fig. 14(b)の き裂がそのまま界面方向へ進むか, 母材方向へ屈曲するか は定かでない.

これらの試験で注目すべき点は, 全疲労寿命の $10 \%$ でシー トセパレーション端部から既に数 $100 \mu \mathrm{m}$ の疲労き裂が発生・ 進展していることである。すなわち全疲労寿命のほとんど が, シートセパレーション端部からの疲労き裂進展寿命で
占められ，疲労き裂発生寿命はほぼ無視できることを示し ている。これらは Tanegashimaらの結果 ${ }^{19)}$ とは異なるが, 鋼 種やシートセパレーション端部の形状に依存するものと考 えられる。一般に，長い疲労き裂の進展特性を疲労き裂進 展速度 $\mathrm{d} a / \mathrm{d} N$ と応力拡大係数範囲 $\Delta K$ の関係で破壊力学的に 評価すると， $\mathrm{d} a / \mathrm{d} N-\Delta K$ 関係にべき乗則（Paris 則）が成り 立つ領域では，鉄鋼の種類や熱処理条件によらず，疲労き 裂進展速度はほぼ同程度になることが知られている ${ }^{15,24,25)}$. これらの結果から，継手の鋼種レベルを変えても継手の疲 労寿命を支配するのは疲労き裂進展であるため, $P-N$ 線図 （Fig.10）では鋼種による明瞭な差が現れなかったと考えら れる。

\section{2 疲労特性に及ぼすナゲット径の影響}

270 および $980 \mathrm{MPa}$ 級鋼板の $4.7 \sqrt{t}$ 材では, Fig. 10 で示し たように $4 \sqrt{t}$ 材とほほ同程度の疲労強度であり, ナゲット 径の影響は現れなかった。これは前項で考察したのと同様, $4.7 \sqrt{t}$ 材でも疲労き裂進展寿命が全寿命の大部分を占めるた めと考えられる。一方 $980 \mathrm{MPa}, 3 \sqrt{t}$ 材のみ有限寿命域にお ける疲労強度が顕著に低下した。これについて検討するた め，270 および $980 \mathrm{MPa} ， 3 \sqrt{t}$ 材を用いて全寿命の $10 \%$ で疲 労試験を中断し，試験片を切断してナゲット周囲の観察を 行った. 前項と同様, 試験荷重は $P_{\text {max }}=3.33 \mathrm{kN}$ (Fig. 15）と $5.56 \mathrm{kN}$ （Fig. 16）の 2 種類であり, 各図の (a) が $270 \mathrm{MPa}$ 材, (b) が $980 \mathrm{MPa}$ 材である.

まず，同一荷重でナゲット径の異なる継手を比較する. $270 \mathrm{MPa}$ 材の場合, $P_{\max }=3.33 \mathrm{kN}$ （Fig.13(a) および 15(a) では，いずれのナゲット径でもまずコロナボンドに沿って
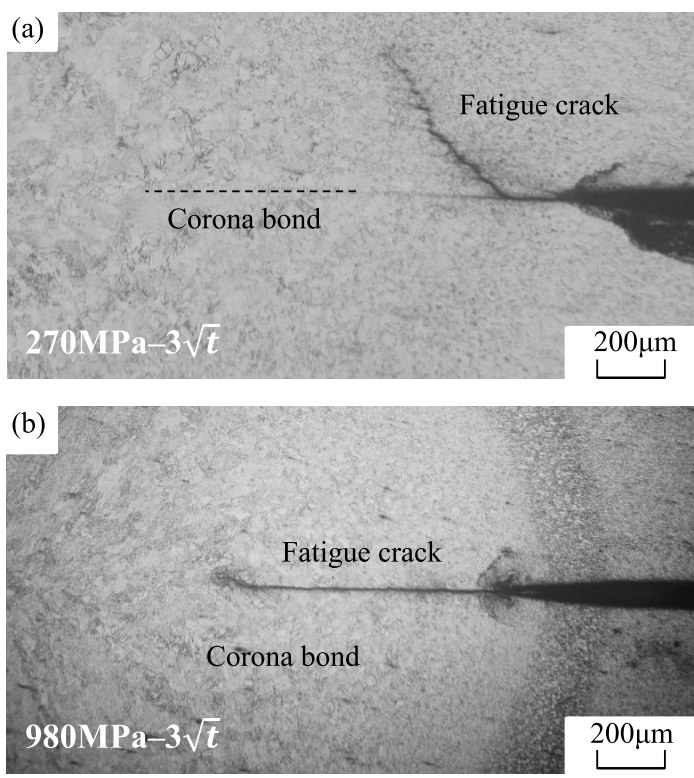

Fig. 15 Interrupted specimens at $10 \%$ of total fatigue life $\left(P_{\max }=3.33 \mathrm{kN}\right)$. The nugget size is $3 \sqrt{t}$.: (a) $270 \mathrm{MPa}$ class, $N=59,448, N_{\mathrm{f}}=$ 594,304 , (b) $980 \mathrm{MPa}$ class, $N=4,173, N_{\mathrm{f}}=41,635$.
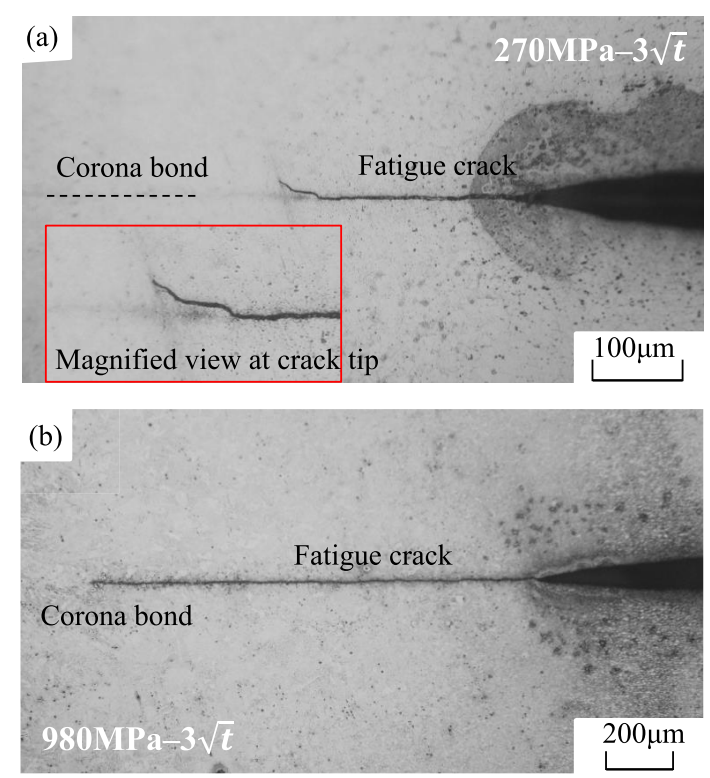

Fig. 16 Interrupted specimens at $10 \%$ of total fatigue life $\left(P_{\max }=5.56 \mathrm{kN}\right)$ The nugget size is $3 \sqrt{t}$.: (a) $270 \mathrm{MPa}$ class, $N=1,712, N_{\mathrm{f}}=$ 16,840 , (b) $980 \mathrm{MPa}$ class, $N=281, N_{\mathrm{f}}=2,751$. 
き裂が発生し, わずかに進展して板厚方向へと屈曲してお り,ほぼ同じ挙動を示している。しかし,コロナボンドに沿っ たき裂進展は，3 $\sqrt{t}$ 材の方が若干長い（Fig.13(a)および 15 (a) は倍率が異なる点に注意)。 $P_{\max }=5.56 \mathrm{kN}$ (Fig. 14 (a) お よび 16(a)）での挙動も同様で, き裂はいずれもコロナボン ドに沿って進展した後, 板厚方向へ屈曲する。この荷重レ ベルでは，コロナボンドに沿ったき裂進展は明らかに $3 \sqrt{t}$ 材の方が長いことがわかる。一方，ナゲット径による相違 は $980 \mathrm{MPa}$ 材の方が明瞭に現れている. $P_{\max }=3.33 \mathrm{kN}$ (Fig. 13(b) および 15(b)）で比較すると，4 $\sqrt{t}$ 材はコロナボ ンドとは無関係にき裂が発生しているが， $3 \sqrt{t}$ 材ではコロナ ボンドに沿って約 $1 \mathrm{~mm}$ き裂が進展している. $P_{\max }=5.56 \mathrm{kN}$ (Fig.14(b) および 16(b)）でも同様で, $3 \sqrt{t}$ 材でのみコロナ ボンドに沿った約 $1 \mathrm{~mm}$ の直線的なき裂進展が認められた. 以上のように, 疲労強度が大きく低下した $980 \mathrm{MPa}, 3 \sqrt{t}$ 材 では，コロナボンドに沿ったき裂進展が疲労寿命の初期で 発生した. Table 3 で示したように同材では最低荷重
$\left(P_{\max }=2.22 \mathrm{kN}\right)$ 以外では全て界面破断となっており, 観察 したき裂はそのまま界面方向へ進展して最終的に界面破断 に至ると考えられる。

以上の結果から，980 MPa，3 $\sqrt{t}$ 材のみで，コロ+ボンド での界面強度が十分ではないことが推察できる。そこで, 静的な引張り試験後の破面観察を行った。引張り試験で界 面破断が生じた $270 \mathrm{MPa} ， 3 \sqrt{t}$ および $4 \sqrt{t}$ 材の破面様相を Fig. 17 に示す。（a）は $3 \sqrt{t}$ 材の巨視的破面，(b)，(c) はそれぞ れ $3 \sqrt{t}$ および $4 \sqrt{t}$ 材のコロナボンド付近拡大眓である. Fig.17(b)，(c) からわかるように，コロナボンド部の破面様 相にはナゲット径による相違は認められなかった。一方, Fig. 18 は $980 \mathrm{MPa} ， 3 \sqrt{t}$ および $4 \sqrt{t}$ 材の破面様相である. Fig.18(b)より明らかに, $3 \sqrt{t}$ 材のコロナボンド部分は平坦 となっており，コロナボンドにおける界面強度が低いこと を示唆している.引張り試験において, Fig.9に示したよう に $980 \mathrm{MPa} ， 3 \sqrt{t}$ 材の最大引張せん断荷重が，鋼板強度レべ ルが高いにもかかわらず, $270 \mathrm{MPa}, 3 \sqrt{t}$ と同程度となった
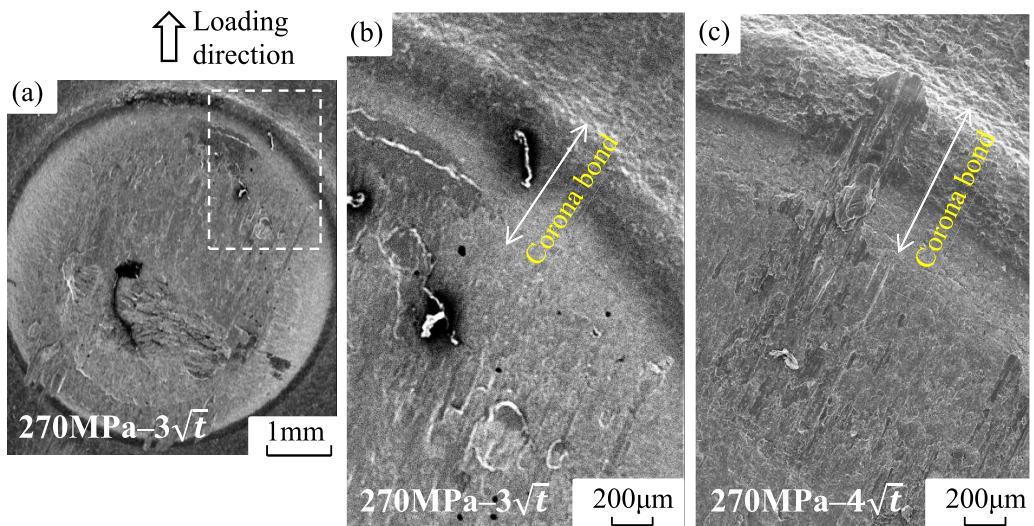

Fig. 17 Fracture surfaces of tensile-shear tests of $270 \mathrm{MPa}$ class RSW joint: (a) Macroscopic view $(3 \sqrt{t})$, (b) Magnified view near corona bond $(3 \sqrt{t})$. The rectangular area in Fig. (a) corresponds to Fig. (b)., (c) Magnified view near corona bond $(4 \sqrt{t})$. Loading direction is vertical.

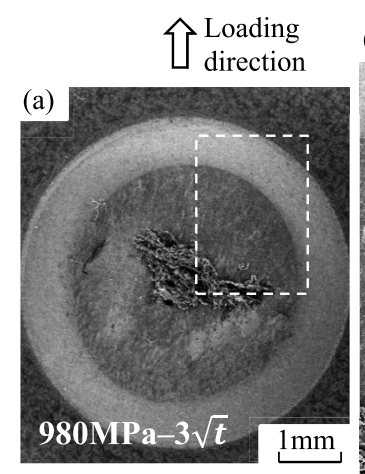

(b)

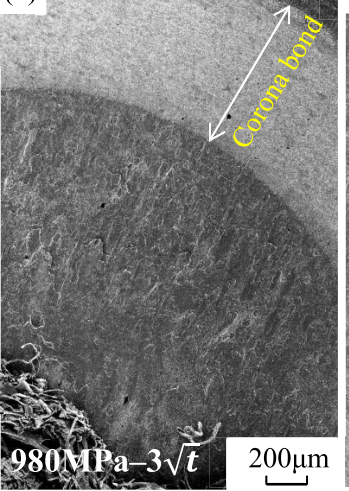

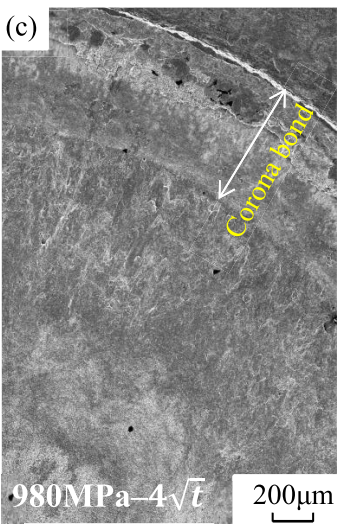

Fig. 18 Fracture surfaces of tensile-shear tests of $980 \mathrm{MPa}$ class RSW joint: (a) Macroscopic view $(3 \sqrt{t})$, (b) Magnified view near corona bond $(3 \sqrt{t})$. The rectangular area in Fig. (a) corresponds to Fig. (b)., (c) Magnified view near corona bond $(4 \sqrt{t})$. Loading direction is vertical. 
ことは，980 MPa， 3 $\sqrt{t}$ 材のコロナボンド界面強度が低いこ とが一因であると考えられる。また，Fig. 19 は $980 \mathrm{MPa}$, $3 \sqrt{t}$ 材の疲労試験 $\left(P_{\max }=3.33 \mathrm{kN}, N_{\mathrm{f}}=41,635\right)$ におけるコ ロナボンド近傍破面様相である。静的破面（Fig. 18(b)）と 同様に, 疲労破面でもコロナボンド部（Fig.19(b)）では平 坦な破面となっている。これらの結果より, $980 \mathrm{MPa}, 3 \sqrt{t}$ 材のコロナボンド部の界面強度が低いため, 有限寿命域に おいて他の継手よりも低寿命になったと結論できる。また $270 \mathrm{MPa}$ でも, コロナボンドに沿ったき裂進展は $3 \sqrt{t}$ 材でわ ずかに長いことから，コロナボンド外周部には部分的に界 面強度の低い箇所が存在し, 疲労寿命が若干短くなったも のと考えられる. シートセパレーション端部, あるいはコ ロナボンドのはく離端部から疲労き裂が進展するか否かで 疲労限度が決まると仮定すると, 疲労き裂進展に対する下 限界応力拡大係数範囲 $\Delta K_{\mathrm{th}}$ が 3 つの鋼種で大きな差がない ため, 疲労限度には鋼種やナゲット径の影響が現れなかっ たと推察される。

Fig. 20 に模式的に示すように，溶接に利用した電極の形 状は全て同一であるため, ナゲット径が小さいほど圧接さ れる領域，すなわちコロナボンドは長くなる． $980 \mathrm{MPa}$ 材に おける断面組織観察で得られた，実際のコロナボンド長さ
とナゲット径の関係を Table 4 に示す. 実測したコロナボン ド長さは, 片側のシートセパレーション端部からナゲット 部までの距離として表記した。表よりナゲット径が小さい ほど，コロナボンドが長いことがわかる，一方，実質的な 接合部と考えられるナゲット径とコロナボンド長さの和も 併記しているが，その值はナゲット径が大きい，すなわち 溶接電流が大きいほど増加する傾向が見られた。コロナボ ンド部では，溶融ナゲット部から距離が離れるほど，温度 こう配が存在するために材料の温度が低下し，それに伴い 塑性変形能も低下する。 その結果, 温度が低いシートセパ レーション近傍ではコロナボンドが圧接しにくくなると考 えられる. $270 \mathrm{MPa}$ 級は降伏点が低いため， $3 \sqrt{t}$ 材でもコロ ナボンドは外周部近傍までほぼ圧接状態にあった。しかし $980 \mathrm{MPa}$ 級は例え高温であっても降伏点が高いため，十分な 圧接が行われず，特に溶融ナゲット部よりも遠方の位置で コロナボンドが未圧接部として残ったと考えられる。

\section{3 疲労強度評価}

Fig.10で示したように，疲労強度に及ぼす鋼種やナゲッ 卜径の影響は小さいが， $3 \sqrt{t}$ 材では低強度となる傾向が見ら れた。そこで疲労強度を統一的に評価できるかを検討する

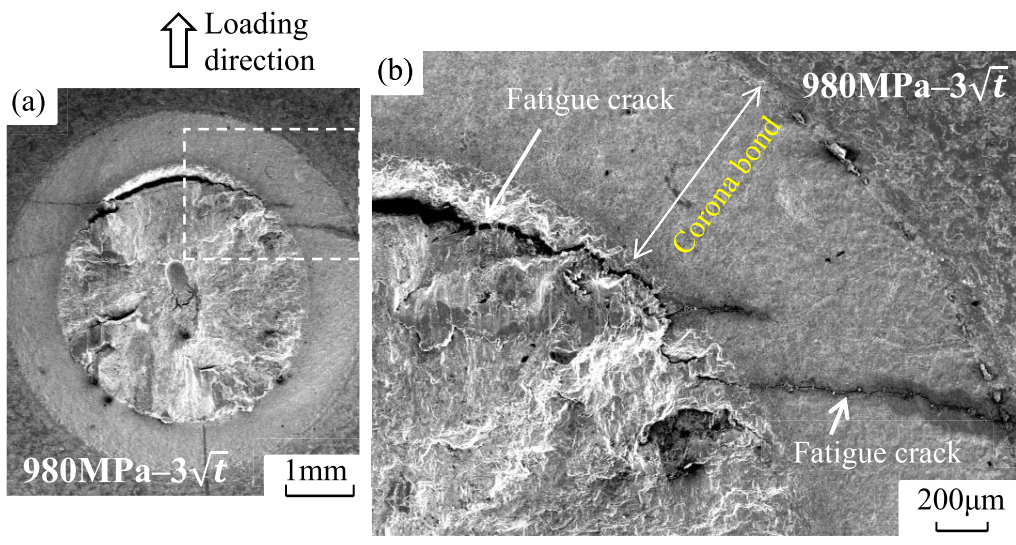

Fig. 19 Fatigue fracture surfaces of tensile-shear tests of $980 \mathrm{MPa}$ class RSW joint $\left(P_{\max }=3.33 \mathrm{kN}, N_{\mathrm{f}}=41,635\right)$. Nugget size is $3 \sqrt{\boldsymbol{t}}:$. (a) Macroscopic view, (b) Magnified view near corona bond. Loading direction is vertical.

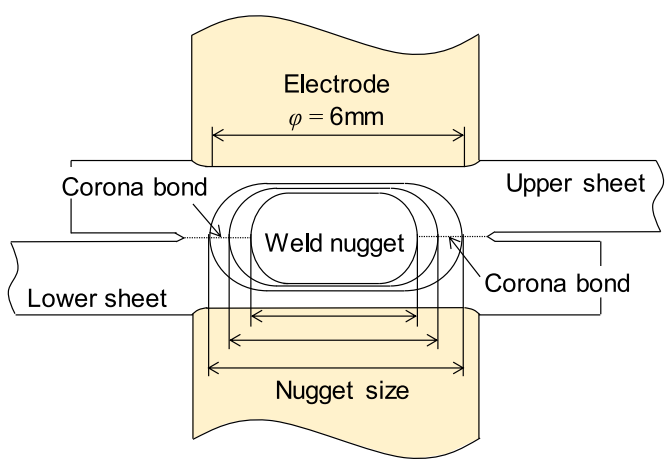

Table 4 Corona bond length.

\begin{tabular}{c|c|c}
\hline \hline Material & $\begin{array}{c}\text { Corona bond length } \\
(\mathrm{mm})\end{array}$ & $\begin{array}{c}\text { Effective nugget size } \\
\text { including corona bond }(\mathrm{mm})\end{array}$ \\
\hline $980-3 \sqrt{t}$ & 1.1 & 5.99 \\
\hline $980-4 \sqrt{t}$ & 0.6 & 6.26 \\
\hline $980-4.7 \sqrt{t}$ & 0.3 & 6.55 \\
\hline
\end{tabular}

Fig.20 Schematic illustration showing corona bond lengths and nugget sizes. 


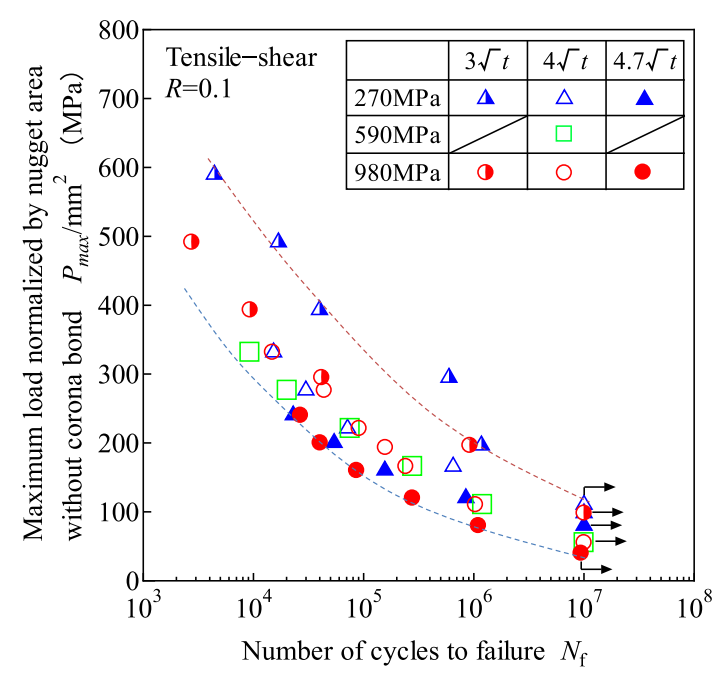

Fig. $21 \quad P-N$ diagram normalized by nugget area.

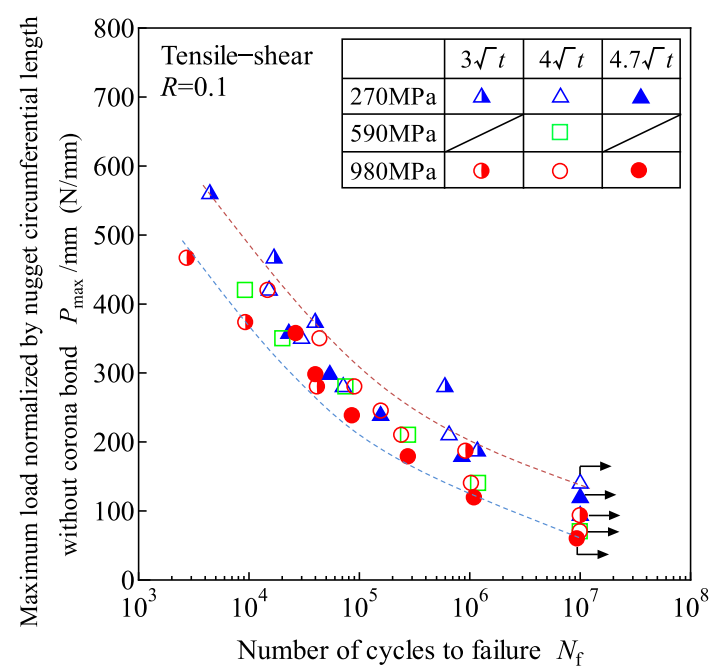

Fig. $22 P-N$ diagram normalized by nugget circumferential length without corona bond.

ため, 試験荷重の正規化を行った. Fig. 21 はナゲット面積, Fig. 22 はナゲット周長によって正規化したものであり，ば らつきの上限と下限を点線で示している. ナゲットの面積 ではなく, 周長に関連するナゲット径によって引張りせん 断強さを推定する式も提案されている ${ }^{13,26}$ が, 本研究におけ る疲労強度についても, ナゲット周長よって正規化した方 が疲労強度の差が小さくなっていることがわかる.なおナ ゲット径は $3 \sqrt{t}, 4 \sqrt{t}$ および $4.7 \sqrt{t}$ としており, コロナボン ドは含んでいない.ここで $980 \mathrm{MPa}, 3 \sqrt{t}$ 材のみコロナボン ド部の界面強度が低く, 他の継手は圧接していた。 そこで, $980 \mathrm{MPa}$ 級の $3 \sqrt{t}$ 材のみコロナボンドを含まず, 他の継手で コロナボンドを含んでナゲット周長による正規化を行った. その結果を Fig. 23 に示す. 図中 $980 \mathrm{MPa}, 3 \sqrt{t}$ 材の結果のみ, コロナボンドを含む場合と含まない場合の周長による正規 化結果を併記している．コロナボンドをナゲット径に含め ると, Table 4 に示したように実質上のナゲット径の差が小

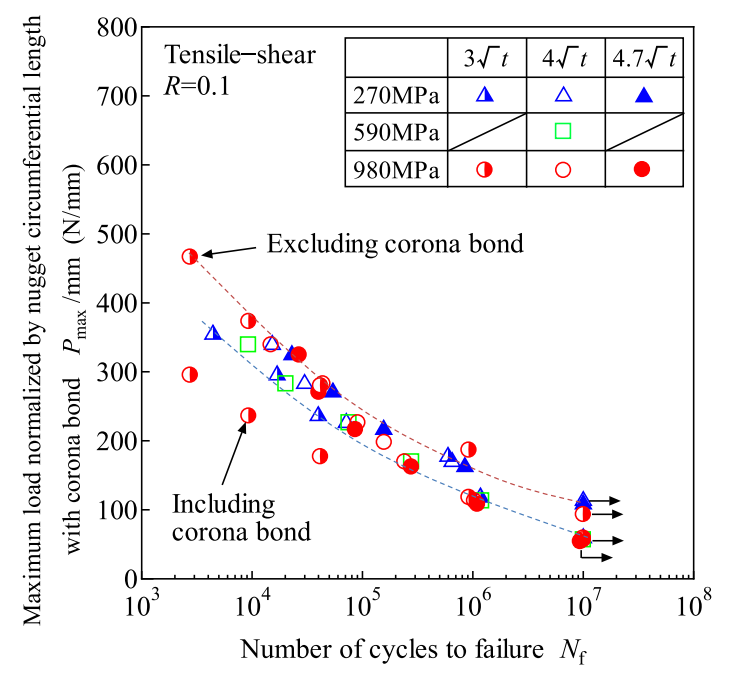

Fig. $23 P-N$ diagram normalized by nugget circumferential length with corona bond.

さくなるため, Fig.10の荷重のみで整理した結果とほぼ同 じ傾向が得られる。しかし $980 \mathrm{MPa}, 3 \sqrt{t}$ 材の結果では, コ ロナボンドを含まずに正規化した方が全体の寿命に漸近し ている。この結果からも， $980 \mathrm{MPa} ３ \sqrt{t}$ 材のコロナボンド の界面強度が他の継手に比べて低いため, 実質的なナゲッ ト径に含むことはできないことを示している.

\section{5. 結言}

本研究では，強度レベルが $270 ， 590 ， 980 \mathrm{MPa}$ と異なる 3 種類の鋼板を用い, 同種鋼板を抵抗スポット溶接 $(\mathrm{RSW}) し$, 継手の引張りせん断疲労強度に及ぼす鋼種の影響について 検討した。また，溶接条件を変えてナゲット径を $3 \sqrt{t}, 4 \sqrt{t}$ および $4.7 \sqrt{t}$ ( $t$ は板厚 $)$ とした試験片も作製し，ナゲット 径の影響についても検討した，得られた主な結果を以下に 示す.

（1）静的な試験における最大引張りせん断荷重については, 母材の強度レベルの上昇, あるいはナゲット径の増加と ともに向上する傾向が見られた。

(2) 疲労試験については, $980 \mathrm{MPa}, 3 \sqrt{t}$ 材のみ疲労強度が 低く，他の継手では鋼板の強度レベルやナゲット径によ らず，疲労強度はほほ同程度となった。疲労中断試験を 行い, ナゲット周りにおけるき裂の有無を確認したとこ ろ, 疲労試験の初期段階で既に疲労き裂が発生している ことが確認された。すなわち，全疲労寿命のほとんどを き裂進展寿命が占めるため, $980 \mathrm{MPa}, 3 \sqrt{t}$ 材を除いて 疲労寿命に鋼種やナゲット径の差が現れなかったと考え られる.

(3) $980 \mathrm{MPa}, 3 \sqrt{t}$ 材のみ有限寿命域での疲労強度が低かっ たが, 破面観察の結果, 同継手のみコロナボンド部の界 面強度が低いことが判明した。コロナボンド部は溶接時 の温度上昇と面圧によって圧接状態にあるが, $980 \mathrm{MPa}$ 
級鋼板は高温下でも降伏応力が高く, ナゲット径が小さ い場合にはコロナボンド部で十分な圧接が生じないた め，界面強度が低くなったと考えられる。

(4) $980 \mathrm{MPa} ， 3 \sqrt{t}$ 材以外の継手では，鋼種やナゲット径に よらずコロナボンド部は圧接状態にあった。すなわち, コロナボンド部が有効なナゲット径に含まれることも, 疲労強度にナゲット径の影響が顕在化しなかった一因であ る.

\section{参 考 文 献}

1) M. Iyota, Y. Mikami, T. Hashimoto, K. Taniguchi, R. Ikeda and M. Mochizuki: Numerical simulation of nugget size and residual stress of resistance spot welded HT980 steel sheet, Q. J. Jpn. Weld. Soc., 29(2011), 86-95. (in Japanese)

2) T. Sadasue, S. Igi, K. Taniguchi, R. Ikeda and K. Oi: Fracture behavior and numerical study of resistance spot welded joints in high strength steel sheet, Q. J. Jpn. Weld. Soc., 32(2014), 64-72. (in Japanese)

3) T. Sadasue, T. Handa, K. Taniguchi, T. Tagawa and R. Ikeda: Effect of sheet thickness on fracture behavior of resistance spot welding joints in high strength steel sheets and dominant factors for fracture toughness, Q. J. Jpn. Weld. Soc., 36(2018), 253-263. (in Japanese)

4) T. Ueda, S. Yokobori, T. Oikawa and H. Kawataka: Fatigue strength of spot welde joint -Effect of pitch on the fatigue strength-, J. Jpn. Weld. Soc., 36(1967), 746-757. (in Japanese)

5) L. P. Pook: Fracture mechanics analysis of the fatigue behaviour of spot welds, Int. J. Frac., 11(1975), 173-176.

6) T. Satoh, J. Katayama and Y. Morii: Investigation of assessment for fatigue strengths of multi-spot welded joints, J. Jpn. Weld. Soc., 50(1981), 496-503. (in Japanese)

7) H. Abe, S. Kataoka and T. Satoh: Empirical formula for fatigue strength of single-spot-welded joints under tensile-shear load, Q. J. Jpn. Weld. Soc., 4(1986), 639-645. (in Japanese)

8) H. Abe and T. Satoh: Non-destructive detection method of fatigue crack in spot-welded joints, Q. J. Jpn. Weld. Soc., 4(1986), 666-673. (in Japanese)

9) Y. Satoh, Y. Ito, T. Shida and S. Minakawa: A study on fatigue strength of spot welded joint, Q. J. Jpn. Weld. Soc., 4(1986), 646652. (in Japanese)

10) C.Z. Li, K. Ohkura, K. Haranaka, M. Shinozaki and H. Kitagawa: Relation between the total fatigue life and the fatigue crack initiation life of a spot weld, Trans. Jpn. Soc. Mech. Eng., Series A, 54(1988), 1716-1722. (in Japanese)

11) C.Z. Li, K. Ohkura, K. Haranaka, M. Shinozaki and H. Kitagawa: A fracture mechanics study on the fatigue crack growth at the spot weld joint, Trans. Jpn. Soc. Mech. Eng., Series A, 55(1989), 231-237. (in Japanese)

12) H. Abe, T. Yokomine, T. Nakaoka and T. Satoh: On the fatigue life of single spot-welded joint under 2-step repeating load-Comparison of results for mild steel with ones for high strength steel-, Q. J. Jpn.
Weld. Soc., 11(1993), 313-320. (in Japanese)

13) K. Yamazaki, K. Satoh and Y. Tokunaga: Static and fatigue strength of spot welded joints of ultrahigh strength steel sheets, Q. J. Jpn. Weld. Soc., 17(1999), 553-560. (in Japanese)

14) K. Tohgo, T. Adomi, H. Araki, K. Syoko, H. Tanaka, S. Usuda and $Y$ Shimamura: Influence of strength level of steels on fatigue strength and fatigue fracture mechanism of spot welded joints, J. Soc. Mater Sci., Jpn., 55(2006), 1095-1101. (in Japanese)

15) K. Tohgo, T. Ohguma, Y. Shimamura and Y. Ojima: FEM analysis study on fatigue strength and fracture morphology in spot welded joints of structural steels, J. Soc. Mater. Sci., Jpn., 58(2009), 627634. (in Japanese)

16) S.H. Lin, J. Pan, P. Wung and J. Chiang: A fatigue crack growth model for spot welds under cyclic loading conditions, Int. J. Fatigue, 28(2006), 792-803.

17) H. Gaul, G. Weber and M. Rethmeier: Influence of HAZ cracks on fatigue resistance of resistance spot welded joints made of advanced high strength steels, Sci. Tech. Weld. Join., 16(2011), 440-445.

18) R. Tanegashima, H. Akebono, M. Kato and A. Sugeta: Establishment of the fatigue cumulative damage evaluation based on the applied load for the spot welded joints using $590 \mathrm{MPa}$-class automobile steel, Trans. Jpn. Soc. Mech. Eng., Series A, 78(2012), 278-288. (in Japanese)

19) R. Tanegashima, H. Akebono, M. Kato and A. Sugeta: 3-Dimensional observation of the interior fracture mechanism and establishment of cumulative fatigue damage evaluation on spot welded joints using $590 \mathrm{MPa}$-class steel, Int. J. Fatigue, 51(2013), 121-131.

20) T. Fujii, K. Tohgo, T. Yamamoto, Y. Suzuki, Y. Shimamura and Y. Ojima: Influence of strength level of steels on fatigue strength and fatigue fracture mechanism of spot weld-bonded joints, J. Soc. Mater. Sci., Jpn., 62(2013), 770-777. (in Japanese)

21) R. Tanegashima, H. Akebono and A. Sugeta: Fatigue life estimation based on fracture mechanics of single spot welded joints under different loading mode, Eng. Frac. Mech., 175(2017), 115-126.

22) J.H. Ordoñes, R.R. Ambriz, C. García, G. Olascencia and D. Jaramillo: Overloading effect on the fatigue strength in resistance spot welding joints of a DP980 steel, Int. J. Fatigue, 121(2019), 163171.

23) M. Kabasawa, Y. Funakawa, K. Ogawa and M. Tamura: Estimation of tensile shear strength of spot welded joint of steel sheets -Resistance spot welded joint strength of steel sheets ( $1^{\text {st }}$ report)-, Q. J. Jpn. Weld. Soc., 14(1996), 754-761. (in Japanese)

24) M. Jono, J. Song, S. Mikami and M. Ohgaki: Fatigue crack growth and crack closure behavior of structural materials, J. Soc. Mater. Sci., Jpn., 33(1984), 468-474. (in Japanese)

25) D. Yang, M. Jono and A. Sugeta: Fatigue crack growth and crack closure under constant amplitude and repeated two-step loadings in a Cr-Mo alloy steel (Effects of heat treatment and microstructure), J Soc. Mater. Sci., Jpn., 38(1989), 1289-1295. (in Japanese)

26) J. Heuschkel: The expression of spot-weld properties, Welding Journal, 31(1952), 931s-943s 